\title{
Streptomyces as Potential Synthetic Polymer Degraders: A Systematic Review
}

\author{
Maria Fernanda Rodríguez-Fonseca ${ }^{1,2}{ }^{\oplus}$, Jeysson Sánchez-Suárez ${ }^{2}{ }^{\circledR}$, Manuel Fernando Valero ${ }^{3}(\mathbb{D}$, \\ Sonia Ruiz-Balaguera ${ }^{4}$ and Luis Eduardo Díaz ${ }^{2, *(D)}$ \\ 1 Master in Process Design and Management, School of Engineering, Universidad de La Sabana, \\ Chía 250001, Colombia; mariarofo@unisabana.edu.co \\ 2 Bioprospecting Research Group, School of Engineering, Universidad de La Sabana, Chía 250001, Colombia; \\ jeyssonsasu@unisabana.edu.co \\ 3 Energy, Materials and Environment Group, School of Engineering, Universidad de La Sabana, \\ Chía 250001, Colombia; manuel.valero@unisabana.edu.co \\ 4 Conservation, Bioprospecting and Sustainable Development Group, Environmental Engineering Program, \\ Universidad Nacional Abierta y a Distancia (UNAD), Bogotá 110911, Colombia; sonia.ruiz@unad.edu.co \\ * Correspondence: luis.diaz1@unisabana.edu.co; Tel.: +57-861-5555 (ext. 25208)
}

check for updates

Citation: Rodríguez-Fonseca, M.F.; Sánchez-Suárez, J.; Valero, M.F.;

Ruiz-Balaguera, S.; Díaz, L.E.

Streptomyces as Potential Synthetic

Polymer Degraders: A Systematic Review. Bioengineering 2021, 8, 154 . https://doi.org/10.3390/

bioengineering 8110154

Academic Editors: Bruna Matturro and Marco Zeppilli

Received: 24 September 2021

Accepted: 20 October 2021

Published: 23 October 2021

Publisher's Note: MDPI stays neutral with regard to jurisdictional claims in published maps and institutional affiliations.

Copyright: (c) 2021 by the authors. Licensee MDPI, Basel, Switzerland. This article is an open access article distributed under the terms and conditions of the Creative Commons Attribution (CC BY) license (https:// creativecommons.org/licenses/by/ $4.0 /)$.

\begin{abstract}
The inherent resistance of synthetic plastics to degradation has led to an increasing challenge of waste accumulation problem and created a pollution issue that can only be addressed with novel complementary methods such as biodegradation. Since biocontrol is a promising eco-friendly option to address this challenge, the identification of suitable biological agents is a crucial requirement. Among the existing options, organisms of the Streptomyces genus have been reported to biodegrade several complex polymeric macromolecules such as chitin, lignin, and cellulose. Therefore, this systematic review aimed to evaluate the potential of Streptomyces strains for the biodegradation of synthetic plastics. The results showed that although Streptomyces strains are widely distributed in different ecosystems in nature, few studies have explored their capacity as degraders of synthetic polymers. Moreover, most of the research in this field has focused on Streptomyces strains with promising biotransforming potential against polyethylene-like polymers. Our findings suggest that this field of study is still in the early stages of development. Moreover, considering the diverse ecological niches associated with Streptomyces, these actinobacteria could serve as complementary agents for plastic waste management and thereby enhance carbon cycle dynamics.
\end{abstract}

Keywords: biodegradation; Streptomyces; polyethylene; polypropylene; plastics; commodity plastics

\section{Introduction}

Natural and synthetic plastics have replaced numerous materials across industries due to their versatility and overall resistance [1]. These plastics have a desirable strength coupled with outstanding flexibility [1,2]. Both natural and synthetic plastics show high resistance against microbial attacks, but synthetic plastics show better performance over long-term exposure [3], and this higher microbial resistance makes them preferred materials in different industries.

Considering the growing importance of synthetic plastics in our daily lives, their production has risen in the past decade, reaching over 348 million tons worldwide in 2017 [3] and projected to reach 500 million tons by the end of 2020 [4]. From this overall production, five plastics, polyethylene terephthalate (PET), high-density polyethylene (HDPE), polyvinyl chloride (PVC), low-density polyethylene (LDPE), and polypropylene (PP) [5], stand out for their massive scales of production and consumption. However, this increase in production and demand has also led to a rise in waste accumulation, since less than 8 million tons ( $\pm 2.3 \%$ of the global production) of plastic are recycled each year worldwide [3], and these five plastics are especially resistant to environmental degradation. 
The growing significance of this plastic waste accumulation is underlined by the negative effects of this waste on human health and the tendency of these materials to persist in the environment for extremely long periods of time [1,2]. In some environments, such as marine systems, plastic pollution can cause physical harm to different animal species [5], with the plastic itself or the byproducts released by the deterioration of the material causing damage to ecosystems and the organisms in it $[1,5]$.

The main concerns associated with plastic waste accumulation are the persistence of this form of waste in every ecosystem and the resultant bioaccumulation of toxic pollutants [6]. Different compounds are released into the environment with the deterioration of plastic materials, including halogenated and aromatic compounds, furans, mercury, brominated compounds, and dioxins [7]. Among these, dioxins are even classified as persistent organic pollutants (POPs) that tend to bioaccumulate and can cause neurological damage, among other health problems [8]. In fact, all of these pollutants have adverse effects on the environment and human health. For instance, they increase air pollution and are linked to problems in the central nervous system, cancer development, and mutations $[1,7,9,10]$.

Micro- and nano-plastics are also a source of considerable concern since the debris of these forms of plastic has been identified in terrestrial and aquatic ecosystems [6,9]. Some studies have shown that $10 \%$ of the total global production of plastics ends up in the ocean [11]. This micro- and nano-plastic debris can cause damage to biological species since it is ingested by organisms and causes adverse effects on the organisms' systems and subsequently bioaccumulates and harms larger organisms [9], thereby affecting the food chain.

Considering the growing scale of this waste management problem, there is an urgent need for the implementation of different methods to control and diminish plastic accumulation in the environment. Because plastic waste is considered hazardous by the Basel Convention, these methods are highly regulated [12]. The byproducts of plastic degradation must be treated as potential hazards as well. The main methods used for the disposal of plastic waste are incineration (pyrolysis), burial or landfilling, and degradation [1]. Incineration and landfilling are the most common methods used at present. In Europe, almost $31 \%$ of plastic waste is landfilled, and up to $39 \%$ is incinerated as an energy recovery method [13]. However, both methods have disadvantages attributable to the inherent properties of these plastics. Incineration requires high temperatures since the majority of the plastics have substantial thermal resistance $[1,13]$, thereby increasing the energetic demand. Moreover, the incineration of plastics is responsible for the release of toxic compounds into the environment, global warming, and other public health issues [1]. On the other hand, disposal in landfills can cause accumulation of plastic waste underground and the release of leachates with highly toxic compounds as potential groundwater pollutants [1].

To address these problems, degradation methods that "weaken" the polymer chain have been proposed to make the subsequent management of plastic waste more accessible [1]. Thermal treatment, UV irradiation, and chemical or physical treatments can be used to degrade plastics and damage their backbone [1], reducing their resistance to environmental abrasion. One degradation method gaining importance is biodegradation, which uses microorganisms to damage the polymer backbone [14]. Biodegradation presents several advantages over other degradation methods since it has minimal negative effects on the environment $[15,16]$.

Biodegradation, or bioremediation, is a helpful strategy to eliminate pollutants from the environment. Microorganisms or their products (such as enzymes) have been used to degrade a wide variety of substrates, including pesticides, heavy metals, and commodity plastics $[15,17,18]$. One of the main advantages of biodegradation is its tendency to induce mineralization [1], in which the substrate is "broken" into smaller and simpler molecules used as an energy source by the microorganisms. The byproducts of these reactions are then used to mineralize the environment in which the microorganism is found $[1,19]$. Mineralization can reduce the deleterious effects of these pollutants on the ecosystems. A crucial point for consideration here is that $100 \%$ biodegradation of synthetic substrates 
is not possible [1], and pretreatment is required to increase the yield of this process [20]. Since synthetic plastics are new materials in the environment, evaluation of microorganisms' adaptation to these plastics is of importance in determining their ability to degrade such substrates [1].

Bacteria and fungi have been studied for their comprehensive metabolism, which allows them to biodegrade different substrates [21-24]. As a result of these abilities, the microorganisms themselves can induce deterioration of different substrates and then degrade them with high efficiency [22,24]. Moreover, some research on the metabolites produced by these microorganisms has shown promising results against natural and synthetic plastics [25-27]. In such assessments, bacteria are preferred over fungi since their growth is faster [28]. Since plastics are relatively new in the environment, well-known bacteria, such as Pseudomonas and Bacillus, as well as the fungus Aspergillus have been widely studied as possible plastic-degrading microorganisms. Some studies have shown that these microorganisms can cause degradation of several synthetic plastics, such as polyvinyl chloride (PVC) and high-density polyethylene (HDPE) [29,30], with PVC films showing up to $19 \%$ weight loss after treatment with the bacterial strains and the HDPE surface showing colonization with dark brown fungus [29,30]. Moreover, Pseudomonas strains have been studied for their ability to induce degradation of natural and synthetic rubber (up to $18 \%$ ), showing the formation of representative degradation byproducts after the incubation time [31].

Another predominant bacterial phylum that is present in several ecosystems and is of increasing importance in the biotechnology field is Actinobacteria. This phylum has been a research target due to its wide and diverse secondary metabolism [32]. Actinobacteria are recognized by their enzyme production and anticancer, antifungal, and antibacterial activities [32]. This phylum has proven to be important for the advancement of pharmaceutical research and biotechnology in general.

Streptomyces are one of the main genera of this phylum. These aerobic, Gram-positive bacteria are essential in the biotechnology field since $75 \%$ of the commonly used antibiotics are derived from these bacteria, and they produce nearly 5000 of the bioactive compounds reported to date [33,34]. These bacteria have shown great potential in several industries, and their enzyme-production characteristics and the ability to degrade polysaccharides [32] make them an interesting alternative for bioremediation and biological control of a wide range of substrates in different ecosystems.

Streptomyces have been studied as bioremediation agents of synthetic $[20,35]$ and natural plastics $[36,37]$. For synthetic plastics, research has shown promising results for deterioration and weight loss of the initial sample. For natural plastics (e.g., cellulose, lignin, and chitin), these bacteria have been shown to degrade almost all the initial samples [38]. Despite this research attention and their potential capabilities, biodegradation of synthetic plastics with Streptomyces has not been studied in detail. However, as stated before, this genus has considerable potential to serve as a solution for the plastic waste accumulation problem. Therefore, this systematic review aimed to identify and evaluate the evidence regarding the potential of Streptomyces strains as biodegrading agents for plastic waste.

\section{Materials and Methods}

\subsection{Search Strategy}

For a broad analysis, the search was conducted using the following databases: Scopus, Web of Science, PubMed, and the Google Scholar search engine. The search terms and Boolean operators used were defined as follows:

- Scopus: TITLE-ABS-KEY (streptomyces AND (plastic OR polymer OR polyethylene OR polystyrene OR polypropylene OR polyurethane OR "polyethylene terephthalate" OR "polyvinyl chloride") AND (degradation OR biodegradation));

- Google Scholar: streptomyces plastic polymer polyethylene polystyrene polypropylene polyurethane "polyethylene terephthalate" "polyvinyl chloride" degradation biodegradation; 
- Web of Science/PubMed: (streptomyces AND (plastic OR polymer OR polyethylene OR polystyrene OR polypropylene OR polyurethane OR "polyethylene terephthalate" OR "polyvinyl chloride") AND (degradation OR biodegradation)).

Figure S1 shows the distribution of the number of hits between the search terms (i.e., Streptomyces, plastics-related and degradation-related).

\subsection{Inclusion and Exclusion Criteria}

The following inclusion criteria were used to select the articles: (a) original research articles, (b) studies evaluating the degrading potential of a Streptomyces strain, and (c) studies on the degradation of synthetic plastic. The exclusion criteria were as follows: (a) articles written in a language other than English, and (b) articles where the determination method for the degradation was not reported.

To avoid bias in article selection, the selection process was performed separately in a blinded manner by each of the three researchers; thus, each researcher assessed the titles and abstracts individually using the Rayyan QCRI tool [39]. An article was marked as potentially included if two researchers indicated that it met the inclusion/exclusion criteria. If only one of the researchers considered the article to have met the inclusion criteria, a discussion was held to address the discrepancies. The potentially included articles were then assessed at the full-text level. The articles that met the inclusion/exclusion criteria at this point were selected for data analysis.

\subsection{Data Collection and Tabulation}

An acquisition form was designed to ensure careful data collection. The form was designed by one researcher and evaluated by another to avoid collection bias. Once the final version of the form was determined, it was used for data collection from the selected articles. Data were tabulated using the form by one researcher and validated by a second researcher.

\section{Results}

\subsection{Selection and Characteristics of Studies}

A total of 1244 non-duplicate articles were identified in the literature search. Since this review was focused on the degradation of synthetic polymers, articles that evaluated the degradation or production of natural polymers were discarded. In the first screening, 1220 studies were excluded because they were not related to synthetic polymer degradation by Streptomyces strains, were not original articles, or did not include access to the full text. Of the 24 remaining articles, 18 were selected by full-text screening on the basis of the inclusion/exclusion criteria and were included for data extraction, as shown in Figure 1.

On the first screening, research on biodegradation of synthetic polymers by Streptomyces strains was noticeably less developed than other bioremediation research, and almost all of the existing research and development seemed to be focused on the same polymer, polyethylene. Despite the increasing relevance of single-use and non-degradable plastics in the plastic waste problem [41], this field has not been studied in-depth since the main waste pollutants in the published studies were not representative of these plastics.

Additionally, despite the bioremediation and enzyme-production potential of Streptomyces and the abundance of this genus in nature, research on synthetic polymer degradation was primarily focused on fungi and other bacteria [22], mainly because of their ability to use almost any complex substrate available in their environment [30].

\subsection{General Findings}

The general findings of this review are summarized in Table 1. As the findings indicate, a variety of synthetic polymers have been studied for biodegradation using Streptomyces strains, although most of the research has been focused on polyethylene-like plastics. Moreover, polymer film samples, such as polymers with linear structures, were the most 
commonly studied due to their availability. The research also showed a large variety of incubation times ranging from 5 to 168 days.

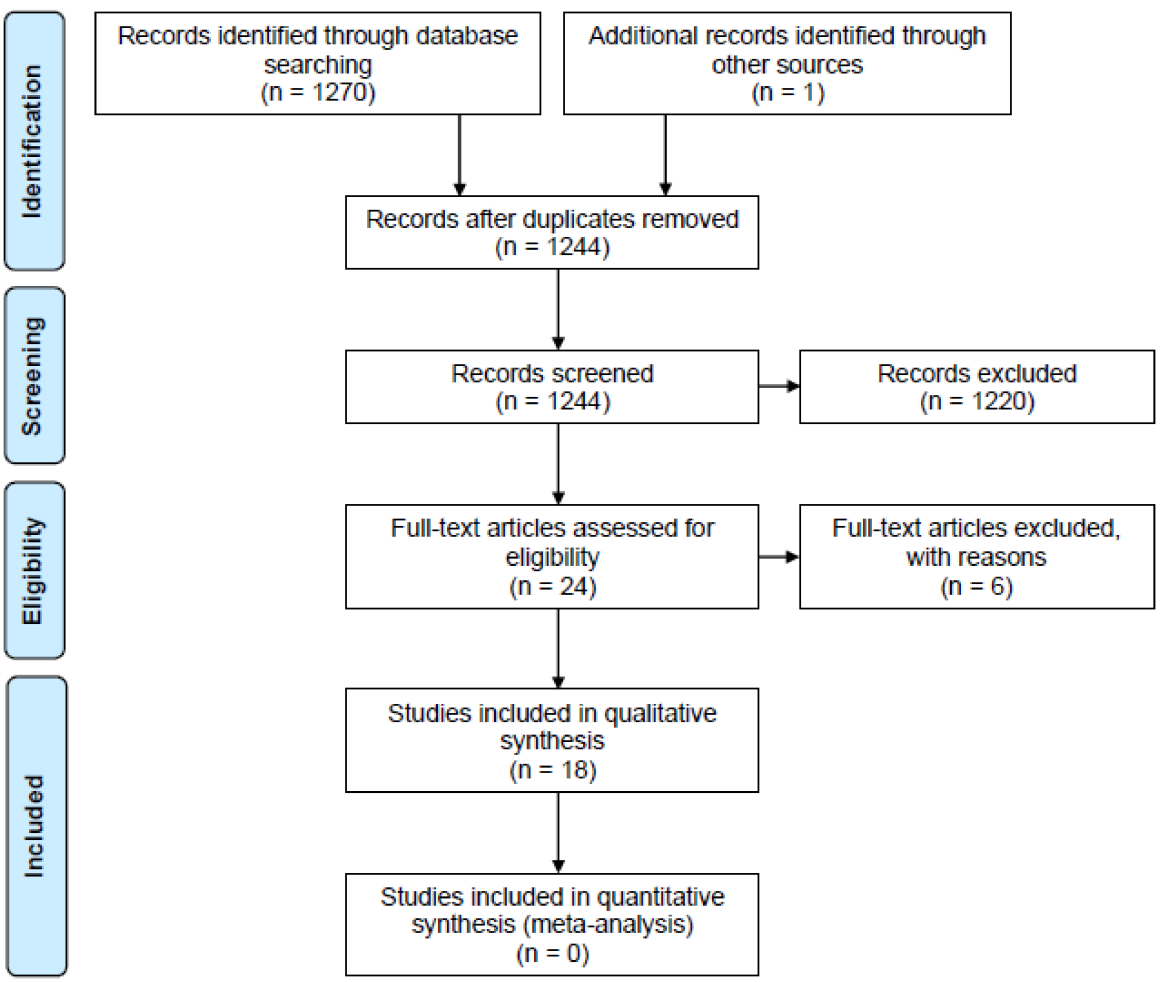

Figure 1. Flowchart of systematic literature search according to PRISMA guidelines. Modified from the work of [40]. The systematic review was done following the PRISMA guidelines, the complete checklist can be reviewed in Table S1.

Table 1. The characteristics and general specifications of the polymers evaluated in the included studies.

\begin{tabular}{|c|c|c|c|c|c|c|}
\hline Polymer & Species & Sample Used & $\begin{array}{l}\text { Polymer } \\
\text { Structure }\end{array}$ & $\begin{array}{c}\text { Time for } \\
\text { Degradation }\end{array}$ & Key Findings & References \\
\hline \multirow{5}{*}{$\begin{array}{l}\text { Low-Density } \\
\text { Polyethylene }\end{array}$} & S. fulvissimus & Compost & Branched $^{a}$ & 21 days & $\begin{array}{l}\text { Volatile compounds } \\
\text { measured }^{1}\end{array}$ & [42] \\
\hline & Streptomyces sp. & Film & Unspecified $^{a}$ & 90 days & $\begin{array}{l}5.2 \% \text { as weight loss } \\
\text { percentage }^{2}\end{array}$ & [43] \\
\hline & Streptomyces sps. & Powder & Branched $^{+}$ & 30 to 168 days & $\begin{array}{l}46.7 \% \text { as weight } \\
\text { loss percentage }\end{array}$ & [44] \\
\hline & $\begin{array}{c}\text { S. badius } \\
\text { (ATCC 39117) } \\
\text { S. setonii } \\
\text { (ATCC 39116) } \\
\text { S. viridosporus } \\
\text { (ATCC 39115) }\end{array}$ & Film & Branched $^{+}$ & 15 days & $\begin{array}{l}\text { Up to } 82 \% \text { reduction in } \\
\text { molecular weight }\end{array}$ & {$[45]$} \\
\hline & Streptomyces sp. & Film & Linear $^{+}$ & 90 days & $\begin{array}{l}0.08 \% \text { as weight } \\
\text { loss percentage }\end{array}$ & [46] \\
\hline \multirow{6}{*}{ Poly(cis-1,4-isoprene) } & $\begin{array}{l}\text { S. griseoplanus } \\
\text { (AS 4.1868T) }\end{array}$ & Liquid & Unspecified $^{\text {a }}$ & 70 days & $\begin{array}{l}\text { Decay on } \\
\text { representative peak }\end{array}$ & [47] \\
\hline & S. coelicolor $1 \mathrm{~A}$ & \multirow{5}{*}{ Film } & \multirow{5}{*}{ Branched $^{+}$} & \multirow{5}{*}{ Unspecified } & $\begin{array}{l}18 \% \text { as weight } \\
\text { loss percentage }\end{array}$ & \multirow{5}{*}{ [31] } \\
\hline & S. exfoliatus (K10) & & & & $<3 \%$ as weight & \\
\hline & & & & & $\begin{array}{l}\text { loss percentage } \\
18 \% \text { as weight }\end{array}$ & \\
\hline & S. griseus 1D & & & & loss percentage & \\
\hline & S. lividans (1326) & & & & $\begin{array}{l}<3 \% \text { as weight } \\
\text { loss percentage }\end{array}$ & \\
\hline
\end{tabular}


Table 1. Cont.

\begin{tabular}{|c|c|c|c|c|c|c|}
\hline Polymer & Species & Sample Used & $\begin{array}{l}\text { Polymer } \\
\text { Structure }\end{array}$ & $\begin{array}{c}\text { Time for } \\
\text { Degradation }\end{array}$ & Key Findings & References \\
\hline \multirow{2}{*}{ Polyester-based } & S. antibioticus & Unspecified & Linear $^{+}$ & 5 to 7 days & $\begin{array}{l}\text { Clear zone formation and } \\
\text { depolymerase production }\end{array}$ & [48] \\
\hline & Streptomyces sp. & $\begin{array}{l}\text { Powder }+ \\
\text { Solvent }\end{array}$ & Linear $^{+}$ & 7 days & Clear zone formation & [49] \\
\hline \multirow{5}{*}{ Polyethylene } & $\begin{array}{l}\text { S. aburaviensis } \\
\text { S. aveblanens } \\
\text { S. iakyrus } \\
\text { S. misioensis } \\
\text { S. warraensis } \\
\text { S. humidus } \\
\text { S. nigellus } \\
\text { S. parvullus }\end{array}$ & Film & Unspecified $^{\mathrm{a}}$ & 7 to 30 days & $\begin{array}{l}\text { An average of } 28.5 \% \\
\text { reduction in } \\
\text { percent elongation }\end{array}$ & {$[50]$} \\
\hline & S. longisporoflavus & Film & Linear $^{+}$ & 60 days & $\begin{array}{l}84.02 \% \text { reduction in } \\
\text { tensile strength }\end{array}$ & [51] \\
\hline & $\begin{array}{l}\text { S. albogriseolus } \\
\text { (LBX-2) }\end{array}$ & Film & Unspecified $^{\mathrm{a}}$ & 15 days & $\begin{array}{l}63 \% \text { reduction in } \\
\text { tensile strength }\end{array}$ & {$[52]$} \\
\hline & $\begin{array}{l}\text { S. badius (ATCC } \\
\text { 39117) } \\
\begin{array}{l}\text { S. setonii (ATCC } \\
\text { 39116) }\end{array} \\
\text { S. viridosporus } \\
\text { (ATCC 39115) }\end{array}$ & Film & Linear $^{+}$ & 30 days & $\begin{array}{l}\text { An average of } 31 \% \\
\text { reduction in } \\
\text { molecular weight } \\
\text { An average of } 36 \% \\
\text { reduction in } \\
\text { molecular weight } \\
\text { An average of } 21 \% \\
\text { reduction in } \\
\text { molecular weight }\end{array}$ & [53] \\
\hline & Streptomyces sp. & Film & Linear $^{+}$ & Up to 55 days & $\begin{array}{l}\text { Up to } 12.04 \% \text { as weight } \\
\text { loss percentage }\end{array}$ & [54] \\
\hline $\begin{array}{l}\text { Polyethylene } \\
\text { terephthalate }\end{array}$ & Streptomyces sp. & Powder & Linear $^{+}$ & 18 days & $\begin{array}{l}\text { Up to } 68 \% \text { as weight } \\
\text { loss percentage }\end{array}$ & [20] \\
\hline Starch-Polyethylene & $\begin{array}{l}\text { S. badius (252) } \\
\text { S. setonii (75Vi2) } \\
\text { S. viridosporus (T7A) }\end{array}$ & Film & Linear $^{+}$ & 20 days & $\begin{array}{l}13.6 \% \text { reduction in } \\
\text { tensile strength } \\
17.2 \% \text { reduction in } \\
\text { tensile strength } \\
12.5 \% \text { reduction in } \\
\text { tensile strength }\end{array}$ & [55] \\
\hline $\begin{array}{l}\text { High-Density } \\
\text { Polyethylene }\end{array}$ & Streptomyces & Powder & Linear $^{+}$ & 18 days & $\begin{array}{l}\text { Up to } 18.26 \% \text { as weight } \\
\text { loss percentage }\end{array}$ & {$[35]$} \\
\hline
\end{tabular}

a Plastic samples were obtained from industrial soil, and no specific data on raw material were obtained. ${ }^{+}$Plastic samples were purchased, and data on raw materials were obtained from suppliers. ${ }^{1}$ Volatile compounds such as octadecane, eicosane, docosane, and tricosane were identified in treatments containing bacteria. No compounds were found in control treatments without bacteria. ${ }^{2}$ Weight loss percentage was measured as the difference between the initial and final weights of the sample after the incubation time. ${ }^{3}$ Decay on the representative peak in HPLC analysis of plastic samples after the incubation time, and samples with no bacterial exposure were used as the negative control. ${ }^{4}$ Clear zone formation was measured as an "inhibition" zone on agar plate mixed with the targeted polymer; if the strain produced a clear zone, the polymer was capable of poly(cos-1,4-isoprene) degradation.

Different methodologies are used to confirm that the polymer was degraded. This review found that studies investigated different outcomes, such as weight loss percentage, decay of the tensile strength, reduction in the elongation percentage, and reduction in the molecular weight, to evaluate polymer degradation, as shown in Table 1 . The results varied depending on the method used, and a mixture of methods was often required to validate and confirm the degradation of the polymer.

As shown in Table 1, one of the main methods used for demonstrating the degradation of polymers was the determination of the weight loss percentage. This technique uses gravimetric principles to determine the weight difference of the samples, assuming that this difference was attributable to the degradation of the polymer's structure. One of the main issues with this method is the high possibility of errors caused by substrate characteristics. For instance, in some studies, the weight difference tended to be higher as the bacteria developed biofilms on the material [31], resulting in increased initial weight and yielding 
false conclusions. This is the main reason why weight loss percentage cannot be used as a single measurement of degradation. Different authors have recommended using a complementary method (i.e., changes in the physicochemical and mechanical properties) to ensure degradation of the polymer's backbone [56]. Methods involving assessment of physicochemical and mechanical properties (e.g., changes in molecular weight, particle size, tensile strength, elongation percentage, and thermal stability) may provide an idea of the degradation process but cannot be used alone since other factors (e.g., sterilization, radiation) can affect the polymer's physicochemical and mechanical properties as well [1]. If the degradation mechanism or the polymer's degradation is well studied and understood, a complementary method can be used to assess specific characteristics of the tested strain (e.g., clear zone formation on rubber degradation and genome sequencing of polyethylenebiodegrading strains) $[31,52]$. Since the methods reported by the included studies were widely dissimilar, it was not possible to perform a meta-analysis of the collected results.

\subsection{Exploration of Plastic Biodegradation by Streptomyces}

Figure 2 shows that Asia and Africa were the main continents where Streptomyces strains with the potential to degrade plastics were isolated (10 and 8 strains, respectively). Egypt and India are the countries leading the search on degrading Streptomyces. However, there is no visible trend in the growth of this field since each country has contributed with almost the same amount of research studies.

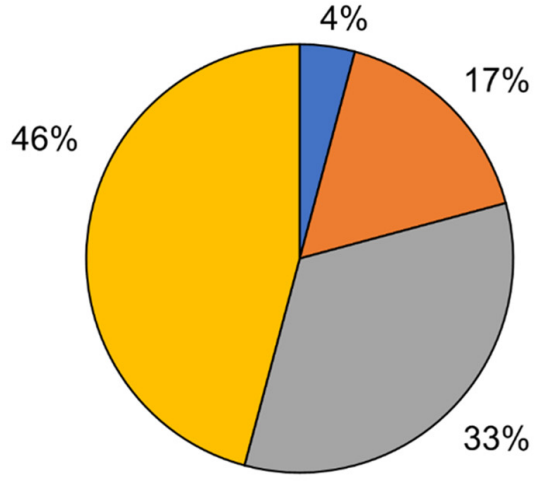

(a)

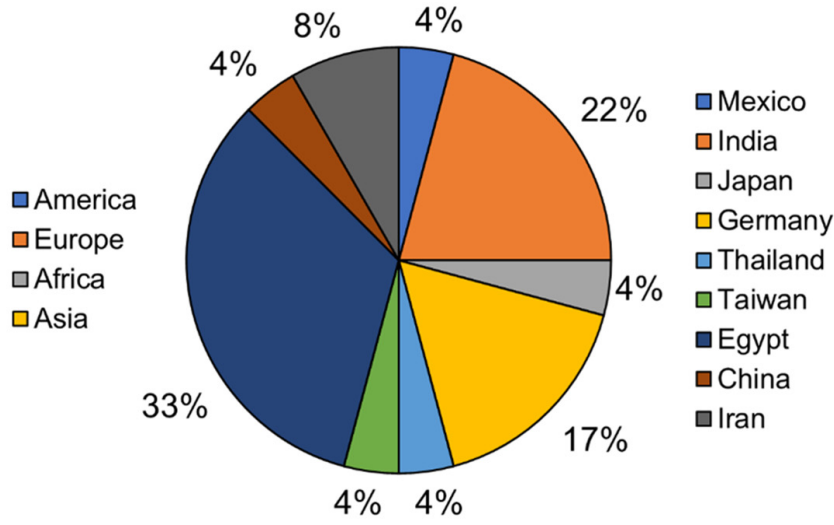

(b)

Figure 2. Main isolation countries for Streptomyces strains capable of plastic biodegradation: (a) Isolated strains' percentage by continent; (b) isolated strains' percentage by country.

Notably, none of the studies were conducted in high waste-producing countries or underdeveloped countries with increasing waste management problems. For instance, in Latin America, the development of research focused on the degradation of synthetic polymers is very poor (i.e., 4 papers in 8 years). Despite the fact that Latin America is mostly an underdeveloped region with an increasingly concerning waste problem, no recent studies have been undertaken to identify solutions for this problem [3,4]. This is an unfortunate scenario considering the biodiversity of countries such as Brazil, Mexico, and Colombia [57].

\section{Isolation Sources}

Soil, mainly contaminated soil from landfills or industrial soil, is the main isolation source for bacteria with the potential for degrading synthetic polymers (Figure 3). The exposure to diverse and complex pollutants in such contaminated soil provides selection pressure to promote microorganisms capable of degrading polymers when these polymers are introduced as the sole carbon source [1]. Unpolluted sources were also studied [58], and the organisms isolated from freshwater sources stand out. Thus, Streptomyces strains isolated from unpolluted sources may also show the ability to assimilate and degrade complex substrates such as synthetic polymers. 


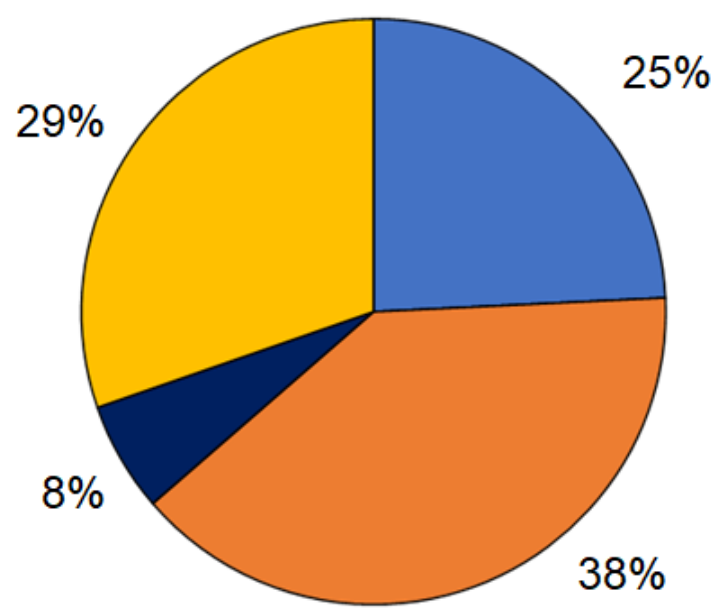

\section{$\square$ Freshwater $\square$ Soil - Symbiont 口Unspecified}

Figure 3. Main isolation sources of Streptomyces strains capable of biodegradation of synthetic polymers.

Symbionts from earthworms were also studied [42], and they have shown positive results in the form of changes in the physical properties (e.g., decay on particle size) of low-density polyethylene (LDPE) samples within 4 weeks of incubation. In this study, bacterial strains were isolated from contaminated sources.

One of the major findings of our study is that marine environments have not been explored. Since plastic debris is a major source of contamination in marine ecosystems [11], the potential of marine Streptomyces (even other actinobacteria genera) from these environments is an unresolved question with an intriguing research scope [11].

\subsection{Enzyme Activity}

One of the main advantages of microorganisms over other biological sources is their relatively simpler genomics. Elucidation of the molecular mechanisms by which the polymer degradation is achieved can provide an opportunity to improve this capability. Considering the thermodynamic proficiency of enzymes, the identification of enzymes responsible for plastic degradation is the next step after isolation of the microorganisms. For example, hydrolases from fungal and bacterial sources have been employed to biotransform synthetic polymers [59]. However, almost no research has been performed to understand or determine enzymatic activity in these degradation processes or their pathways [60]. Depolymerase-like lipase/esterase, oxygenase, and amylase from bacterial sources have shown positive results in different studies [30,48,52], using techniques such as clear zone formation on agar plates, optimization for enzyme production, specific enzyme activity tests, and whole-genome sequencing. These tests showed the production of enzymes by the Streptomyces strains studied, but they did not draw correlations between the production of the enzyme and substrate degradation.

Bode et al., 2001 [31] showed a hypothetical oxidative pathway for the conversion of poly(cis-1,4-isoprene) to acetyl-coenzymeA and propionyl-coenzymeA. Although this was the only study to propose an enzymatic pathway for polymer degradation by Streptomyces strains, the authors did not report if the enzyme was being produced by the strains under experimental conditions with the target polymer as a carbon source.

\section{Discussion}

A notable aspect of the literature is the repetition of identified strains across studies since the same species were often studied with the same polymer $[45,61]$, with changes in some experimental variables such as time of exposure. Moreover, some studies have used bacterial consortia to increase the biodegradation rate of xenobiotic pollutants [56], relying on the synergistic activity of multiple strains to degrade the pollutants and their byproducts. However, even though enhanced rates of biodegradation have been reported in these studies, none of these reports described the use of Streptomyces consortia. 
Despite the well-known ability of Streptomyces to degrade several kinds of polymers (e.g., PET, PP, and LDPE) and the significant negative impact of plastic pollution, we found few studies that evaluated Streptomyces as a possible agent of biological control. In comparison with other microorganisms such as Pseudomonas cholororaphis, Aspergillus brasiliensis, and Chaetomium globosum, which achieved synthetic plastic biodegradation rates between $9 \%$ and $13 \%$ [62], Streptomyces showed promising activity that deserves further study. Moreover, some studies evaluated the effect of pretreatments on the polymer sample (i.e., grinding the sample, radiation, etc.) [20] and concluded that this technique can enhance the degradation.

Depending on the structure of the sample polymer, measures can be taken to facilitate the process of degradation. For example, higher yields can be obtained with smaller molecules, such as powders, since the superficial area of these materials is higher, better contact is achieved between the microorganisms and the polymer, and the rate of degradation is higher [20]. Moreover, the nature of the sample can have a positive effect on the process and outcomes of degradation; for example, plasticized samples tend to be less degradable since microorganisms degrade plasticizers but not the polymer backbone $[63,64]$.

Another remarkable aspect is the diversity of sources from which the strains in these studies were isolated. Notably, strains isolated from polluted sources (i.e., landfills) tended to have higher yields, which could be attributed to their adaptation to xenobiotic compounds in their native environment [30]. Thus, microorganisms such as bacterial strains from these environments may have hitherto unexplored bioremediation ability [41]. Therefore, marine environments can be an excellent isolation source for further studies and advancements in this field of research.

Considering the diversity of techniques and methodologies used to identify degradation, two or more methods should be used together to obtain more reliable and accurate results. For example, while weight loss on its own can lead to false conclusions and physical changes in the material can be due to external factors [31], a combination of these techniques could more accurately demonstrate the occurrence of plastic degradation.

The primary theory underlying the degradation of these xenobiotic compounds is that they involve enzymatic action since they are complex pollutants [34,65]. One of the insights of this review is that almost no research has been conducted on enzymatic activities or biodegradation pathways, and no genes of specific bacteria have been studied for their role in the degradation of synthetic polymers. These gaps in the existing literature represent promising areas of research since the identification of enzymes or genes that are specifically responsible for polymers' degradation could facilitate the development of new waste management methods with high yields using Streptomyces strains. Sharing the GeneBank access codes of the identified strains is recommended since no phylogenetic analysis could be carried out with the available information. This step can help in further research to identify similar potential strains in the field.

As the metabolic pathways involved in plastic degradation are still underdeveloped, some studies have been focused on understanding and modeling the biodegradation process for selected strains [20,35], aiming to improve the scale-up of these processes and comprehend the bacterial behavior under controlled conditions. These models have been adjusted to first-order kinetic models, showing high adjustment rates on predicting biodegradation of specific polymers by selected strains [20,35], being useful in the design of new bioprocesses at industrial levels, giving solutions on larger scales to the pollution issue regarding plastic waste accumulation. These bioprocesses could lead to a permanent, efficient, and eco-friendly solution, replacing the traditional waste management options available (i.e., incineration, landfills).

\section{Conclusions}

Biological control of plastic pollution represents a promising and eco-friendly management option. In this study, Streptomyces strains showed notable potential for degrading synthetic polymers, particularly polyethylene-like polymers. Although the research on 
biotransformation of single-use plastics is limited, the results obtained so far indicate that studies with this genus are an encouraging research field. On the other hand, despite the widespread use of weight loss as a measure of degradation, it is important to complement weight loss measurements with findings from another method based on a different measurement principle, such as changes in the mechanical properties of the materials or byproduct analysis associated with degradation stages. It is noteworthy that the selected biodegradation or biotransformation approach has to consider the polymer target and the type of sample used (e.g., powder, film, liquid) due to these features represent a methodological challenge for a successful analysis. Certainly, centering the attention on understanding metabolic pathways or kinetic processes could get to a significant breakthrough in implementing these solutions on larger scales. Likewise, enzymatic identification and biochemical characterization, including whole-genome analysis of the known strains, could be helpful in the study of synthetic polymer degraders. We highly recommend and look forward to further research in this area in the upcoming years.

Supplementary Materials: The following are available online at https:/ / www.mdpi.com/article/ 10.3390/bioengineering8110154/s1, Table S1: PRISMA checklist, Figure S1: Venn diagram analysis showing the distribution and relationship between hit results of the search equations.

Author Contributions: Conceptualization, M.F.R.-F., L.E.D. and J.S.-S.; methodology, M.F.R.-F. and J.S.-S.; software, M.F.R.-F. and J.S.-S.; validation, M.F.R.-F., L.E.D., J.S.-S. and M.F.V.; formal analysis, M.F.R.-F.; investigation, M.F.R.-F.; resources, L.E.D., S.R.-B. and M.F.V.; data curation, M.F.R.-F., L.E.D. and J.S.-S.; writing—original draft preparation, M.F.R.-F.; writing—review and editing, J.S.-S., L.E.D. and M.F.V.; visualization, M.F.R.-F., L.E.D. and J.S.-S.; supervision, L.E.D.; project administration, L.E.D. and M.F.V.; funding acquisition, S.R.-B. and L.E.D. All authors have read and agreed to the published version of the manuscript.

Funding: This research was funded by Universidad Nacional Abierta y a Distancia (UNAD), project number PS072020 and by Universidad de La Sabana, project number ING-204-2018.

Institutional Review Board Statement: Not applicable.

Informed Consent Statement: Not applicable.

Acknowledgments: To Universidad de La Sabana for the Graduate Assistant Scholarship. To GIBP and Actinos Group for their support. To Rodinson Arrieta for all the advice and patience.

Conflicts of Interest: The authors declare no conflict of interest.

\section{References}

1. Tripathi, S.; Yadav, A.; Tripathi, D.M. Plastic Waste: Environmental Pollution, Health Hazards and Biodegradation Strategies. In Bioremediation of Industrial Waste for Environmental Safety; Springer Nature: Singapore, 2016; pp. 99-133.

2. Andrady, A.L.; Neal, M.A. Applications and societal benefits of plastics. Philos. Trans. R. Soc. B Biol. Sci. 2009, 364, 1977-1984. [CrossRef] [PubMed]

3. Association of Plastics Manifacturors. Plastics—The Facts 2018; Plastics Europe: Brussels, Belgium, 2018.

4. Greenpeace España. Datos Sobre la Producción de Plásticos. Available online: https://es.greenpeace.org/es/trabajamos-en/ consumismo/plasticos/datos-sobre-la-produccion-de-plasticos/ (accessed on 9 September 2019).

5. Rochman, C.M.; Hoh, E.; Hentschel, B.T.; Kaye, S. Long-term field measurement of sorption of organic contaminants to five types of plastic pellets: Implications for plastic marine debris. Environ. Sci. Technol. 2013, 47, 1646-1654. [CrossRef] [PubMed]

6. Bejgarn, S.; MacLeod, M.; Bogdal, C.; Breitholtz, M. Toxicity of leachate from weathering plastics: An exploratory screening study with Nitocra spinipes. Chemosphere 2015, 132, 114-119. [CrossRef]

7. Verma, R.; Vinoda, K.S.; Papireddy, M.; Gowda, A.N.S. Toxic Pollutants from Plastic Waste- A Review. Procedia Environ. Sci. 2016, 35, 701-708. [CrossRef]

8. Hites, R.A. Dioxins: An overview and history. Environ. Sci. Technol. 2011, 45, 16-20. [CrossRef]

9. Chae, Y.; An, Y.-J. Current research trends on plastic pollution and ecological impacts on the soil ecosystem: A review. Environ. Pollut. 2018, 240, 387-395. [CrossRef]

10. Groh, K.J.; Backhaus, T.; Carney-Almroth, B.; Geueke, B.; Inostroza, P.A.; Lennquist, A.; Leslie, H.A.; Maffini, M.; Slunge, D.; Trasande, L.; et al. Overview of known plastic packaging-associated chemicals and their hazards. Sci. Total Environ. 2019, 651, 3253-3268. [CrossRef] 
11. Avio, C.G.; Gorbi, S.; Regoli, F. Plastics and microplastics in the oceans: From emerging pollutants to emerged threat. Mar. Environ. Res. 2017, 128, 2-11. [CrossRef]

12. UNEP Consideration of the Implementation of the Basel Convention Technical Matters: Preparation of Technical Guidelines. Available online: http:/ / www.basel.int/Implementation/Publications/GuidanceManuals/tabid/2364/Default.aspx (accessed on 11 September 2019).

13. Yu, J.; Sun, L.; Ma, C.; Qiao, Y.; Yao, H. Thermal degradation of PVC: A review. Waste Manag. 2016, 48, 300-314. [CrossRef]

14. Ahmed, T.; Shahid, M.; Azeem, F.; Rasul, I.; Shah, A.A.; Noman, M.; Hameed, A.; Manzoor, N.; Manzoor, I.; Muhammad, S. Biodegradation of plastics: Current scenario and future prospects for environmental safety. Environ. Sci. Pollut. Res. 2018, 25, 7287-7298. [CrossRef]

15. Jenkins, S.; Quer, A.M.; Fonseca, C.; Varrone, C. Microbial Degradation of Plastics: New Plastic Degraders, Mixed Cultures and Engineering Strategies. Soil Microenviron. Bioremediat. Polym. Prod. 2019, 213-238.

16. Pathak, V.M.; Bisht, T.S.; Navneet; Pandey, A. Biodegradation of Natural and Synthetic Polymer: A Microbial Approach for a Sustainable Environment. In Microbial Biotechnology in Environmental Monitoring and Cleanup; IGI Global: Hershey, PA, USA, 2018; pp. 106-124.

17. Bidlan, R.; Manonmani, H.K. Aerobic degradation of dichlorodiphenyltrichloroethane (DDT) by Serratia marcescens DT-1P. Process. Biochem. 2002, 38, 49-56. [CrossRef]

18. Ahuactzin-Pérez, M.; Tlecuitl-Beristain, S.; García-Dávila, J.; González-Pérez, M.; Gutiérrez-Ruíz, M.C.; Sánchez, C. Degradation of di(2-ethyl hexyl) phthalate by Fusarium culmorum: Kinetics, enzymatic activities and biodegradation pathway based on quantum chemical modelingpathway based on quantum chemical modeling. Sci. Total Environ. 2016, 566-567, 1186-1193. [CrossRef] [PubMed]

19. Shah, A.A.; Hasan, F.; Hameed, A.; Ahmed, S. Biological degradation of plastics: A comprehensive review. Biotechnol. Adv. 2008, 26, 246-265. [CrossRef] [PubMed]

20. Farzi, A.; Dehnad, A.; Fotouhi, A.F. Biodegradation of polyethylene terephthalate waste using Streptomyces species and kinetic modeling of the process. Biocatal. Agric. Biotechnol. 2019, 17, 25-31. [CrossRef]

21. Trivedi, P.; Hasan, A.; Akhtar, S.; Haris Siddiqui, M.; Sayeed, U.; Kalim, M.; Khan, A. Role of microbes in degradation of synthetic plastics and manufacture of bioplastics. J. Chem. Pharm. Res. 2016, 8, 211-216.

22. Pathak, V.; Navneet. Review on the current status of polymer degradation: A microbial approach. Bioresour. Bioprocess. 2017, 4, 15. [CrossRef]

23. Usha, R.; Sangeetha, T.; Palaniswamy, M. Screening of Polyethylene Degrading Microorganisms from Garbage Soil. Libyan Agric. Res. Cent. J. Int. 2011, 2, 200-204.

24. Wilkes, R.A.; Aristilde, L. Degradation and metabolism of synthetic plastics and associated products by Pseudomonas sp.: Capabilities and challenges. J. Appl. Microbiol. 2017. [CrossRef]

25. Mueller, R.-J. Biological degradation of synthetic polyesters-Enzymes as potential catalysts for polyester recycling. Process. Biochem. 2006, 41, 2124-2128. [CrossRef]

26. Almeida, E.L.; Rincón, A.F.C.; Jackson, S.A.; Dobson, A.D.W. In silico Screening and Heterologous Expression of a Polyethylene Terephthalate Hydrolase (PETase)-Like Enzyme (SM14est) With Polycaprolactone (PCL)-Degrading Activity, From the Marine Sponge-Derived Strain Streptomyces sp. SM14. Front. Microbiol. 2019, 10, 2187. [CrossRef] [PubMed]

27. Nanthini, J.; Ong, S.Y.; Sudesh, K. Identification of three homologous latex-clearing protein (lcp) genes from the genome of Streptomyces sp. strain CFMR 7. Gene 2017, 628, 146-155. [CrossRef]

28. Sharma, S.R. Bioremediation of Polythenes and Plastics: A Microbial Approach. In Approaches in Bioremediation; Springer: Cham, Switzerland, 2018; pp. 97-114.

29. Giacomucci, L.; Raddadi, N.; Soccio, M.; Lotti, N.; Fava, F. Polyvinyl chloride biodegradation by Pseudomonas citronellolis and Bacillus flexus. New Biotechnol. 2019, 52, 35-41. [CrossRef]

30. Poonam, K.; Rajababu, V.; Yogeshwari, J.; Patel, H. Diversity of plastic degrading microorganisms and their appraisal on biodegradable plastic. Appl. Ecol. Environ. Res. 2013, 11, 441-449. [CrossRef]

31. Bode, H.B.; Kerkhoff, K.; Jendrossek, D. Bacterial degradation of natural and synthetic rubber. Biomacromolecules 2001, 2, 295-303. [CrossRef]

32. Barka, E.A.; Vatsa, P.; Sanchez, L.; Gaveau-Vaillant, N.; Jacquard, C.; Klenk, H.-P.; Clément, C.; Ouhdouch, Y.; van Wezel, G.P. Taxonomy, Physiology, and Natural Products of Actinobacteria. Microbiol. Mol. Biol. Rev. 2016, 80, 1-43. [CrossRef]

33. Chater, K.F. Recent advances in understanding Streptomyces. F1000Research 2016, 5, 2795. [CrossRef]

34. Chater, K.F.; Biró, S.; Lee, K.J.; Palmer, T.; Schrempf, H. The complex extracellular biology of Streptomyces: Review Article. FEMS Microbiol. Rev. 2010, 34, 171-198. [CrossRef] [PubMed]

35. Farzi, A.; Dehnad, A.; Shirzad, N.; Norouzifard, F. Biodegradation of high density polyethylene using Streptomyces species. J. Coast. Life Med. 2017, 5, 474-479. [CrossRef]

36. Lacombe-Harvey, M.-Ë; Brzezinski, R.; Beaulieu, C. Chitinolytic functions in Actinobacteria: Ecology, enzymes, and evolution. Appl. Microbiol. Biotechnol. 2018, 102, 7219-7230. [CrossRef] [PubMed]

37. Větrovský, T.; Steffen, K.T.; Baldrian, P. Potential of cometabolic transformation of polysaccharides and lignin in lignocellulose by soil Actinobacteria. PLoS ONE 2014, 9, e89108. [CrossRef] 
38. Meng, X.; Shao, Z.; Hong, Y.; Lin, L.; Li, C.; Liu, Z. A novel pH-stable, bifunctional xylanase isolated from a deep-sea microorganism, Demequina sp. JK4. J. Microbiol. Biotechnol. 2009, 19, 1077-1084.

39. Ouzzani, M.; Hammady, H.; Fedorowicz, Z.; Elmagarmid, A. Rayyan-A web and mobile app for systematic reviews. Syst. Rev. 2016, 5, 210. [CrossRef]

40. Moher, D.; Liberati, A.; Tetzlaff, J.; Altman, D.G. Preferred Reporting Items for Systematic Reviews and Meta-Analyses: The PRISMA Statement. PLoS Med. 2009, 6, e1000097. [CrossRef] [PubMed]

41. Ali, S.S.; Elsamahy, T.; Koutra, E.; Kornaros, M.; El-Sheekh, M.; Abdelkarim, E.A.; Zhu, D.; Sun, J. Degradation of conventional plastic wastes in the environment: A review on current status of knowledge and future perspectives of disposal. Sci. Total Environ. 2021, 771, 144719. [CrossRef]

42. Lwanga, E.H.; Thapa, B.; Yang, X.; Gertsen, H.; Salánki, T.; Geissen, V.; Garbeva, P. Decay of low-density polyethylene by bacteria extracted from earthworm's guts: A potential for soil restoration. Sci. Total Environ. 2018, 624, 753-757. [CrossRef]

43. Gajendiran, A.; Krishnamoorthy, S.; Abraham, J. Microbial degradation of low-density polyethylene (LDPE) by Aspergillus clavatus strain JASK1 isolated from landfill soil. 3 Biotech 2016, 6, 1-6. [CrossRef]

44. Deepika, S.; Madhuri, J.R. Biodegradation of Low Density Polyethylene By Micro-Organisms From Garbage Soil. J. Exp. Biol. Agric. Sci. 2015, 3, 15-21.

45. Weiland, M.; Daro, A.; David, C. Biodegradation of thermally oxidized polyethylene. Polym. Degrad. Stab. 1995, 48, 275-289. [CrossRef]

46. Abraham, J.; Ghosh, E.; Mukherjee, P.; Gajendiran, A. Microbial degradation of low density polyethylene. Environ. Prog. Sustain. Energy 2017, 36, 147-154. [CrossRef]

47. Imai, S.; Ichikawa, K.; Muramatsu, Y.; Kasai, D.; Masai, E.; Fukuda, M. Isolation and characterization of Streptomyces, Actinoplanes, and Methylibium strains that are involved in degradation of natural rubber and synthetic poly(cis-1,4-isoprene). Enzyme Microb. Technol. 2011, 49, 526-531. [CrossRef]

48. Sriyapai, P.; Chansiri, K.; Sriyapai, T. Isolation and Characterization of Polyester-Based Plastics-Degrading Bacteria from Compost Soils. Microbiology 2018, 87, 290-300. [CrossRef]

49. Hoang, K.-C.; Lee, C.-Y.; Tseng, M.; Chu, W.S. Polyester-degrading actinomycetes isolated from the Touchien River of Taiwan. WORLD J. Microbiol. Biotechnol. 2007, 23, 201-205. [CrossRef]

50. El-Shafei, H.A.; El-Nasser, N.H.A.; Kansoh, A.L.; Ali, A.M. Biodegradation of disposable polyethylene by fungi and Streptomyces species. Polym. Degrad. Stab. 1998, 62, 361-365. [CrossRef]

51. Shahnawaz, M.; Sangale, M.K.; Ade, A.B. Rhizosphere of Avicennia marina (Forsk.) Vierh. as a landmark for polythene degrading bacteria. Environ. Sci. Pollut. Res. 2016, 23, 14621-14635. [CrossRef] [PubMed]

52. Shao, H.; Chen, M.; Fei, X.; Zhang, R.; Zhong, Y.; Ni, W.; Tao, X.; He, X.; Zhang, E.; Yong, B.; et al. Complete genome sequence and characterization of a polyethylene biodegradation strain, Streptomyces albogriseolus LBX-2. Microorganisms 2019, 7, 379. [CrossRef]

53. Lee, B.; Pometto, A.L., III; Fratzke, A.; Bailey, T.B., Jr. Biodegradation of degradable plastic polyethylene by Phanerochaete and Streptomyces species. Appl. Environ. Microbiol. 1991, 57, 678-685. [CrossRef]

54. Kannahi, M.; Sudha, P. Screening of polythene and plastic degrading microbes from Muthupet mangrove soil. J. Chem. Pharm. Res. 2013, 5, 122-127.

55. Pometto, A.L., III; Lee, B.T.; Johnson, K.E. Production of an extracellular polyethylene-degrading enzyme(s) by Streptomyces species. Appl. Environ. Microbiol. 1992, 58, 731-733. [CrossRef]

56. Giacomucci, L.; Raddadi, N.; Soccio, M.; Lotti, N.; Fava, F. Biodegradation of polyvinyl chloride plastic films by enriched anaerobic marine consortia. Mar. Environ. Res. 2020, 158, 104949. [CrossRef]

57. Sasson, A.; Malpica, C. Bioeconomy in Latin America. New Biotechnol. 2018, 40, 40-45. [CrossRef] [PubMed]

58. Tseng, M.; Hoang, K.-C.; Yang, M.-K.; Yang, S.-F.; Chu, W.S. Polyester-degrading thermophilic actinomycetes isolated from different environment in Taiwan. Biodegradation 2007, 18, 579-583. [CrossRef] [PubMed]

59. Knott, B.C.; Erickson, E.; Allen, M.D.; Gado, J.E.; Graham, R.; Kearns, F.L.; Pardo, I.; Topuzlu, E.; Anderson, J.J.; Austin, H.P.; et al. Characterization and engineering of a two-enzyme system for plastics depolymerization. Proc. Natl. Acad. Sci. USA 2020, 117, 25476-25485. [CrossRef] [PubMed]

60. Mohanan, N.; Montazer, Z.; Sharma, P.K.; Levin, D.B. Microbial and Enzymatic Degradation of Synthetic Plastics. Front. Microbiol. 2020, 11, 2837. [CrossRef]

61. Pometto, A.L., III; Lee, B. Process of Biodegradation of High Molecular Weight Polyethylene by Aerobic Lignolytic Microorganisms. U.S. Patent 5145779A, 8 September 1992.

62. Vivi, V.K.; Martins-Franchetti, S.M.; Attili-Angelis, D. Biodegradation of PCL and PVC: Chaetomium globosum (ATCC 16021) activity. Folia Microbiol. 2019, 64, 1-7. [CrossRef] [PubMed]

63. Webb, J.S.; Nixon, M.; Eastwood, I.M.; Greenhalgh, M.; Robson, G.D.; Handley, P.S. Fungal colonization and biodeterioration of plasticized polyvinyl chloride. Appl. Environ. Microbiol. 2000, 66, 3194-3200. [CrossRef]

64. Bialecka-Florjańczyk, E.; Florjańczyk, Z. Solubility of Plasticizers, Polymers and Environmental Pollution. In Thermodynamics, Solubility and Environmental Issues; Elsevier: Amsterdam, The Netherlands, 2007; pp. 397-408. ISBN 978-0444527073.

65. Bhatti, A.A.; Haq, S.; Bhat, R.A. Actinomycetes benefaction role in soil and plant health. Microb. Pathog. 2017, 111, 458-467. [CrossRef] 